\title{
A Glycosidic Spinasterol from Koreana stewartia Promotes Procollagen Production and Inhibits Matrix Metalloproteinase-1 Expression in UVB-Irradiated Human Dermal Fibroblasts
}

\author{
Tae Hoon Lee, ${ }^{a}$ Sang Min LeE, ${ }^{a}$ Dae-Young LeE,,${ }^{a}$ Youngsook Son, ${ }^{a, b}$ Dae Kyun Chung, ${ }^{a, c}$ \\ Nam-In BAEK, ${ }^{a}$ and Jiyoung KIM*,a \\ ${ }^{a}$ Graduate School of Biotechnology and College of Life Science, Kyung Hee University; ${ }^{b}$ Musculoskeletal Bioorgan \\ Center, Kyung Hee University; and ${ }^{c}$ Skin Biotechnology Center, Kyung Hee University; Yongin 446-701, Korea. \\ Received September 20, 2010; accepted February 7, 2011; published online February 18, 2011
}

Methanol extract of Koreana stewartia leaves (SKE) stimulated collagen production in ultraviolet-B (UVB)irradiated human fibroblast cells. An active compound was isolated from SKE by successive partitioning and chromatography, and the chemical structure was determined to be $3-O$ - $\beta$-D-glucopyranosylspinasterol (spinasterol-Glc) by spectroscopic characterization. Spinasterol-Glc increased collagen production in the supernatant of UVB-irradiated dermal fibroblast cell cultures in a dose-dependent manner. The effects of spinasteol-Glc on expression of procollagen and matrix metalloproteinase-1 (MMP-1) were further evaluated. We found that the compound stimulated collagen production in UVB-treated fibroblasts than in vehicle-treated control cells by about 3-fold. In addition, we also demonstrate that the compound increased the mRNA and protein levels of procollagen in UVB-treated fibroblast cells, while it inhibited expression of MMP-1. These results indicate that spinasterol-Glc protects fibroblast cells from the adverse effects of UV radiation via stimulation of procollagen synthesis as well as inhibition of MMP-1 expression. Spinasterol-Glc may be useful in the future development of therapeutic and cosmetic applications.

Key words photoaging; spinasterol; collagen; matrix metalloproteinase-1; Stewartia koreana

UV irradiation, particularly that of UVB $(290-320 \mathrm{~nm})$, causes various adverse effects to human skin, the most serious being skin cancer and premature skin aging (photoaging). ${ }^{1-3)}$ The functional properties of skin depend on the integrity of collagens, which are the most abundant structural proteins in dermis. ${ }^{4)}$ Type 1 collagen, which accounts for $70-90 \%$ of all collagen, is synthesized by fibroblasts as a soluble precursor, type 1 procollagen, secreted and proteolytically processed to form insoluble collagen fibers in the dermis. ${ }^{5,6)}$ The production and fibrillar organization of collagen in the skin are reduced by UV irradiation whereas gene expression of matrix metalloproteinases (MMPs) is increased. ${ }^{7)}$ Among MMPs, MMP-1 is the most responsible for the degradation of type 1 collagen in the skin. ${ }^{8-10)}$ Collagen degradation and inhibition of collagen production impair the structural integrity of the skin during photoaging. Therefore, control of collagen metabolism may be useful for a variety of therapeutic and cosmetic applications.

Recently, a variety of herbs and plants have traditionally been used in cosmetic applications for the treatment of collagen synthesis and collagenase inhibition. ${ }^{1-15)}$ It has been widely reported that natural compounds from plants are potential sources of MMP inhibitors, which may prevent or mitigated UV-induced skin aging. ${ }^{16-18)}$ Stewartia koreana (Theaceae), a deciduous tree, is native to Korea and grows throughout the whole area of Korea. It prefers a partly shaded to full sun area, and favors a rich, moist, well-drained, and acidic loam. The leaves are dark green, elliptical, and mildly serrulate, and alternately arranged on stem. In autumn, the leaves turn a bright red to reddish purple. Usually in July, white solitary flowers bloom with $5-6$ petals and yellow stamens. The flowers open wider with a more flattened look than most other species of Stewartia. The fruits ripen as an inconspicuous pentagon-shaped one in October.

\footnotetext{
* To whom correspondence should be addressed. e-mail: jkim@khu.ac.kr

The bark is well exfoliated, ranging in color from soft grays and tans to orange and reddish browns. ${ }^{19)}$

We previously reported that Stewarita koreana extract induced angiogenesis and extracellular matrix (ECM) remodeling in a mouse model. It has also been reported that alcohol extracts from Stewartia koreana stimulate vasculization in $v i v o^{20)}$ but there is no report for the individual components of the plant. In addition, our preliminary experiments showed that the alcohol extracts were very effective in restoring wounds on punched skin of the back of mice. Therefore, this study was initiated to determine the principal components that manifest the biological activity. We isolated a number of compounds from Stewarita koreana extract. In the present study, we identified an active compound, 3-O- $\beta$-D-glucopyranosylspinasterol (spinasterol-Glc), and investigated its effect on the levels of collagen and on the expression of MMP-1 in UVB-treated fibroblast cells. We found that spinasterol-Glc inhibits collagen degradation in UVB-induced fibroblast cells, suggesting a protective role against the adverse effects of UV irradiation.

\section{MATERIALS AND METHODS}

Extraction and Isolation of 3-O- $\beta$-D-Glucopyranosylspinasterol (Spinasterol-Glc) The air-dried leaves of $S$. koreana $(8.5 \mathrm{~kg})$ were cut and extracted with $80 \%$ aqueous $\mathrm{MeOH}(201 \times 2)$ twice for $12 \mathrm{~h}$ at room temperature. The methanol extracts were successively partitioned using EtOAc $(21 \times 2), n$ - $\mathrm{BuOH}(21 \times 2)$, and $\mathrm{H}_{2} \mathrm{O}(21)$. Each fraction was concentrated in vacuo to give EtOAc ( $89 \mathrm{~g}), n-\mathrm{BuOH}(73 \mathrm{~g})$, and aqueous $(122 \mathrm{~g})$ fractions. The EtOAc fraction $(80 \mathrm{~g})$ was applied to silica gel column chromatography $(10 \times 20 \mathrm{~cm})$ and eluted with $n$-hexane-EtOAc $(7: 1 \rightarrow 5: 1 \rightarrow 3: 1 \rightarrow 1: 1) \rightarrow$ $\mathrm{CHCl}_{3}-\mathrm{MeOH}(10: 1 \rightarrow 7: 1 \rightarrow 5: 1 \rightarrow 3: 1 \rightarrow 1: 1)$ monitoring 
by thin layer chromatography to provide seventeen fractions (SKE1 to SKE17). Fractions SKE7 and SKE8 were pooled and subjected to $\mathrm{SiO}_{2}$ column chromatography $(5 \times 13 \mathrm{~cm})$ using $\mathrm{CHCl}_{3}-\mathrm{MeOH}(17: 1)$ as the eluent to yield ten fractions (SKE7-1 to SKE7-10). Subfraction SKE7-4 (532 mg) was subjected to $\mathrm{SiO}_{2}$ column chromatography $(4 \times 10 \mathrm{~cm})$ with $\mathrm{CHCl}_{3}-\mathrm{MeOH}(10: 1)$ to produce six fractions (SKE74-1 to SKE7-4-6). Subfraction SKE7-4-3 (129 mg) was applied to Octadesyl silica gel (ODS) column chromatography $(3 \times 10 \mathrm{~cm})$ and eluted with $\mathrm{MeOH}-\mathrm{H}_{2} \mathrm{O}(2: 1)$ to ultimately afford 3-O- $\beta$-D-glucopyranosylspinasterol (spinasterol-Glc). [17 mg, TLC (RP-18 $\left.\mathrm{F}_{254}\right)$ Rf 0.53, $\left.\mathrm{MeOH}-\mathrm{H}_{2} \mathrm{O}(5: 1)\right]$.

3-O- $\beta$-D-Glucopyranosylspinasterol, white powder $(n$ hexane- $\left.\mathrm{CHCl}_{3}\right)$; mp $280^{\circ} \mathrm{C}$; $[\alpha]_{\mathrm{D}}^{25}-12.6^{\circ}(c=0.17$, pyridine); negative FAB-MS m/z: $573[\mathrm{M}-1]^{-}, 411[\mathrm{M}-\mathrm{glc}]^{-}$, $395[\mathrm{M}-\mathrm{Oglc}]^{-}$; IR $v\left(\mathrm{CHCl}_{3}, \mathrm{~cm}^{-1}\right) 3341 ;{ }^{1} \mathrm{H}-\mathrm{NMR}(400$ $\left.\mathrm{MHz}, \mathrm{C}_{5} \mathrm{D}_{5} \mathrm{~N}\right) \delta_{\mathrm{H}}: 5.22(1 \mathrm{H}, \mathrm{m}, \mathrm{H}-7), 5.22(1 \mathrm{H}, \mathrm{dd}, J=16.0$, $8.8 \mathrm{~Hz}, \mathrm{H}-22), 5.07$ (1H, dd, $J=16.0,8.8 \mathrm{~Hz}, \mathrm{H}-23), 5.02$ $\left(1 \mathrm{H}, \mathrm{d}, J=7.2 \mathrm{~Hz}, \mathrm{H}^{-1} 1^{\prime}\right), 3.54(1 \mathrm{H}, \mathrm{m}, \mathrm{H}-3), 1.06(3 \mathrm{H}, \mathrm{d}, J=$ $6.4 \mathrm{~Hz}, \mathrm{H}-21), 0.89$ (3H, d, $J=6.0 \mathrm{~Hz}, \mathrm{H}-26), 0.85$ (3H, d, $J=$ $6.0 \mathrm{~Hz}, \mathrm{H}-27), 0.85(3 \mathrm{H}, \mathrm{t}, J=6.4 \mathrm{~Hz}, \mathrm{H}-29), 0.71(3 \mathrm{H}, \mathrm{s}, \mathrm{H}-$ 19), 0.57 (3H, s, H-18); ${ }^{13} \mathrm{C}-\mathrm{NMR}\left(100 \mathrm{MHz}, \mathrm{C}_{5} \mathrm{D}_{5} \mathrm{~N}\right) \delta_{\mathrm{C}}$ : 139.60 (C-8), 138.69 (C-22), 129.65 (C-23), 117.89 (C-7), $102.32\left(\mathrm{C}-1^{\prime}\right), 78.77\left(\mathrm{C}-3^{\prime}\right), 78.62\left(\mathrm{C}-5^{\prime}\right), 77.16(\mathrm{C}-3), 75.49$ $\left(\mathrm{C}-2^{\prime}\right), 71.88\left(\mathrm{C}-4^{\prime}\right), 63.04\left(\mathrm{C}-6^{\prime}\right), 56.15(\mathrm{C}-17), 55.42(\mathrm{C}-$ 14), 51.57 (C-24), 49.72 (C-9), 43.61 (C-13), 41.29 (C-20), 40.31 (C-5), 39.76 (C-12), 37.47 (C-1), 34.89 (C-10), 34.70 (C-4), 32.33 (C-25), 30.19 (C-2, C-6), 29.09 (C-16), 25.87 (C-28), 23.52 (C-15), 21.93 (C-21), 21.81 (C-11), 21.48 (C27), 19.32 (C-26), 13.25 (C-19), 12.72 (C-29), 12.43 (C-18).

General Experimental Procedures Optical rotations were measured on a P-1010 digital polarimeter (Jasco, Tokyo, Japan). Melting points were measured with a Fisher-John's Melting Point Apparatus (Fisher Scientific, Waltham, MA, U.S.A.) and were not corrected. FAB/MS data were recorded on JMSAX 505-WA and JMS-700 spectrometers (JEOL, Tokyo, Japan) and IR spectra were run on a Spectrum One FT-IR Spectrometer (Perkin-Elmer, Waltham, MA, U.S.A.). ${ }^{1} \mathrm{H}-\mathrm{NMR}(400 \mathrm{MHz})$ and ${ }^{13} \mathrm{C}-\mathrm{NMR}(100 \mathrm{MHz})$ spectra were taken on a Unity Inova AS 400 FT-NMR spectrometer (Varian Inc., Lake Forest, CA, U.S.A.).

Cell Culture Primary cultures of dermal fibroblast were established from human foreskins. Normal human dermal fibroblasts (NHDF) were maintained and grown in FGM-2 medium (Clonetics, Walkersville, MD, U.S.A.) containing 2\% fetal bovine serum (Invitrogen, Carlsbad, CA, U.S.A.), $0.1 \%$ recombinant human fibroblast growth factor (rhFGF), $0.1 \%$ insulin, 5 units $/ \mathrm{ml}$ heparin, 100 units $/ \mathrm{ml}$ of penicillin, and $100 \mu \mathrm{g} / \mathrm{ml}$ of streptomycin in a humidified incubator of $5 \% \mathrm{CO}_{2}$ at $37^{\circ} \mathrm{C}$.

MTT Assay Cell viability was determined by 3-(4,5dimethyl-2-thiazolyl)-2,5-diphenyl-2 $H$-tetrazoliumbromide (MTT) assay. NHDF cells $\left(1 \times 10^{4}\right.$ cells/well) were maintained in culture media, washed three times with phosphate buffered saline (PBS) and then seeded into 96-well plates. Various amounts of spinasterol-Glc were then treated for $48 \mathrm{~h}$. Cell viability was evaluated in each well by the addition of $50 \mu \mathrm{l}$ of MTT. After $1 \mathrm{~h}$ of incubation, the cell-free supernatants were removed completely from each well, and $100 \mu \mathrm{l}$ of dimethyl sulfoxide was added. Absorbance was measured at $540 \mathrm{~nm}$ using a spectrophotometric multiwell microplate reader (Multiskan MS; Thermo Electron Corp., Waltham, MA, U.S.A.).

UV Irradiation The fibroblast cells were grown in cell culture plates and the medium was subsequently replaced by $2 \mathrm{ml}$ of PBS. After washing, the cells were treated with or without spinasterol-Glc in serum free media for $24 \mathrm{~h}$ and then irradiated with UVB $\left(20 \mathrm{~mJ} / \mathrm{cm}^{2}\right)$ at $312 \mathrm{~nm}$ for $15 \mathrm{~s}$ using a UVB lamp (Bio-Sun Lamps, Vilber Lourmat, Marine, France), which delivered uniform irradiation at a distance of $15 \mathrm{~cm}$ and monitored the radiation intensities using JIC 119 (BEC, Brookline, MA, U.S.A.) as described. ${ }^{21)}$

Measurement of Collagen Total soluble collagen in cell culture supernatants was quantified using the SirCol collagen assay kit (Biocolor Ltd., Belfast, Northern Ireland) as previously described. ${ }^{22}$ For these experiments, confluent cells were incubated for $24 \mathrm{~h}$ in 24 -well plates. One milliliter of Sirius red dye, an anionic dye that reacts specifically with basic side-chain groups of collagens under assay conditions, was added to $400 \mu \mathrm{l}$ supernatant, followed by incubation under gentle rotation for $30 \mathrm{~min}$ at room temperature. After centrifugation at $12000 \times \boldsymbol{g}$ for $10 \mathrm{~min}$, the collagen-bound dye was redissolved with $1 \mathrm{ml}$ of $0.5 \mathrm{M} \mathrm{NaOH}$, and the absorbance was measured at $540 \mathrm{~nm}$ in a microplate enzymelinked immunosorbent assay reader (Dynex Technologies, Chantilly, VA, U.S.A.).

Reverse Transcriptase-Polymerase Chain Reaction (RT-PCR) Total RNA was prepared from human fibroblasts cells using a Trizol Reagent kit (Invitrogen, Carlsbad, CA, U.S.A.) as previously described. ${ }^{23)}$ Total RNA $(2 \mu \mathrm{g})$ was reverse transcribed using $\mathrm{M}-\mathrm{MuLV}$ reverse transcriptase (Fermentas Life Science, Glen Burnie, MD, U.S.A.). The primers used for polymerase chain reaction (PCR) amplification in this study were as follows: MMP-1, forward 5'AGCGTGTGACAGTAAGCTAA-3' and reverse 5'-GTTTTCCTCAGAAAGAGCAGCAT-3'; procollagen, forward 5'CTCGAGGTGGACACCACCCT-3' and reverse 5'-CAGCTGGATGGCCACATCGG-3'; $\beta$-actin mRNA levels were used as internal controls. The cycling conditions were as follow: initial denaturation at $95^{\circ} \mathrm{C}$ for $10 \mathrm{~min}$, followed by 28 amplification cycles of $95^{\circ} \mathrm{C}$ for $15 \mathrm{~s}, 58^{\circ} \mathrm{C}$ for $5 \mathrm{~s}$ and $72^{\circ} \mathrm{C}$ for $15 \mathrm{~s}$.

Western Blot Analysis Fibroblast cells were lysed in radio immunoprecipitation assay (RIPA) buffer $(150 \mathrm{~mm}$ sodium chloride, $1 \%$ Triton $\mathrm{X}-100,1 \%$ sodium deoxycholate, $0.1 \%$ sodium dodecyl sulfate (SDS), $50 \mathrm{~mm}$ Tris- $\mathrm{HCl} \mathrm{pH}$ 7.5, 2 mm ethylenediaminetetraacetic acid (EDTA)) containing proteinase inhibitor cocktails (Roche, Indianapolis, IN, U.S.A.). Protein concentrations were quantified with a protein assay kit (Bio-Rad Laboratories, Philadelphia, PA, U.S.A.). Proteins ( $20 \mu \mathrm{g} /$ lane) were resolved with SDS-polyacrylamide gel electrophoresis, and Western blot analysis was performed as described previously. ${ }^{19)}$ Human anti-MMP-1 and human anti-procollagen (R\&D Systems, Minneapolis, MN, U.S.A.) were utilized as primary antibodies, and peroxidaseconjugated antibody was used as a secondary antibody. The membranes were developed with an enhanced chemiluminescence system from GE healthcare (Buckinghamshire, U.K.) and exposed for $30 \mathrm{~s}$ to X-ray film (Fuji Photo Film Co., Ltd., Japan).

Statistical Analysis Unless otherwise stated, all experiments were performed with triplicate samples and repeated at 
least three times. The data are presented as means \pm S.D. and statistical comparisons between groups were performed using 1-way analysis of variance (ANOVA) followed by Student's $t$-test.

\section{RESULTS}

Characterization of an Active Compound from the Leaves of Stewartia koreana It has been reported that Stewarita koreana extract induced angiogenesis and ECM remodeling in a mouse model. ${ }^{20}$ In order to isolate an active compound, the leaves of Stewarita koreana were extracted with $80 \% \mathrm{MeOH}$ and the obtained extracts were partitioned successively with EtOAc, $n$-BuOH, and water as shown in Fig. 1A. The stimulatory activity of collagen production was mainly found in EtOAc phase. The EtOAc extract $(80 \mathrm{~g})$ was applied to the silica gel column chromatography $(10 \times 20 \mathrm{~cm})$ and eluted with $n$-hexane-EtOAc $(7: 1 \rightarrow 5: 1 \rightarrow 3: 1 \rightarrow 1: 1) \rightarrow$ $\mathrm{CHCl}_{3}-\mathrm{MeOH}(10: 1 \rightarrow 7: 1 \rightarrow 5: 1 \rightarrow 3: 1 \rightarrow 1: 1)$ monitoring by thin layer chromatography to provide seventeen fractions (SKE1 to SKE17). As shown Fig 1B, fractions 3 and 4 and fractions 7 and 8 promoted collagen production, while fractions 14 to 16 slightly increased collagen production in UVB-irradiation fibroblast cells (Fig. 1B). The active compounds were isolated by the repeated $\mathrm{SiO}_{2}$ and ODS column chromatography.

The most active compound, a white powder, appeared as a dark purple color on the TLC by spraying with $10 \%$ aq. $\mathrm{H}_{2} \mathrm{SO}_{4}$ followed by heating. It showed absorbance bands due to the hydroxy group $\left(3341 \mathrm{~cm}^{-1}\right)$ in the IR spectrum. The molecular weight was determined to be 574 from the molecular ion $[\mathrm{M}-1]^{-}$at $m / z 573$ in the negative FAB-MS spectrum. In the ${ }^{1} \mathrm{H}-\mathrm{NMR}\left(400 \mathrm{MHz}, \mathrm{C}_{5} \mathrm{D}_{5} \mathrm{~N}\right)$ spectrum, three olefin methines $\left[\delta_{\mathrm{H}} 5.22, \delta_{\mathrm{H}} 5.22, \delta_{\mathrm{H}} 5.07\right]$ proton signals were observed. Two of them were the signals of a double bond with trans-configuration, which were revealed from the coupling constant $(J=16.0 \mathrm{~Hz})$ between the olefin protons. Also, we observed one oxygenated-methine $\left(\delta_{\mathrm{H}} 3.54\right)$ as well as many proton signals due to a sugar, that is, a hemiacetal $\left(\delta_{\mathrm{H}} 5.02, \mathrm{~d}, J=7.2 \mathrm{~Hz}\right)$, several oxygenated-methines, and an oxygenated-methlylene from $\delta_{\mathrm{H}} 3.85$ to $\delta_{\mathrm{H}} 4.55$. In the high magnetic field, six methyls including two singlets $\left(\delta_{\mathrm{H}} 0.71\right.$, $\left.\delta_{\mathrm{H}} 0.57\right)$, three doublets $\left(\delta_{\mathrm{H}} 1.06, \mathrm{~d}, J=6.4 \mathrm{~Hz} ; \delta_{\mathrm{H}} 0.89, \mathrm{~d}\right.$, $\left.J=6.0 \mathrm{~Hz} ; \delta_{\mathrm{H}} 0.85, \mathrm{~d}, J=6.0 \mathrm{~Hz}\right)$, and one triplet $\left(\delta_{\mathrm{H}} 0.85, \mathrm{t}\right.$, $J=6.4 \mathrm{~Hz}$ ) proton signals were identified. The aforementioned ${ }^{1} \mathrm{H}-\mathrm{NMR}$ data allowed the assumption that the compound was a stigmastane-type sterol glycoside. The ${ }^{13} \mathrm{C}$ NMR (100 MHz, $\left.\mathrm{C}_{5} \mathrm{D}_{5} \mathrm{~N}\right)$ spectrum showed 35 carbon signals confirming the compound to be a glycoside composed of a stimastane-type sterol and a hexose. The sugar was identified as $\beta$-D-glucopyranose from the chemical shifts of one hemiacetal $\left(\delta_{\mathrm{C}} 102.32\right)$, four oxygenated-methines $\left(\delta_{\mathrm{C}} 78.77, \delta_{\mathrm{C}}\right.$ $\left.78.62, \delta_{\mathrm{C}} 75.49, \delta_{\mathrm{C}} 71.88\right)$, and one oxygenated-methylene $\left(\delta_{\mathrm{C}} 63.04\right)$ carbon signals. The configuration of the anomer hydroxy, $\beta$, was also confirmed from the coupling constant $(J=7.2 \mathrm{~Hz})$ of the anomer proton signal at $\delta_{\mathrm{H}} 5.02$. The carbon signals of the aglycon included one olefin quaternary $\left(\delta_{\mathrm{C}}\right.$ $139.60)$, three olefin methines $\left(\delta_{\mathrm{C}} 138.69, \delta_{\mathrm{C}} 129.65, \delta_{\mathrm{C}}\right.$ $117.89)$, one oxygenated methine $\left(\delta_{\mathrm{C}} 77.16\right)$, and six methyl carbons $\left(\delta_{\mathrm{C}} 21.93, \delta_{\mathrm{C}} 21.48, \delta_{\mathrm{C}} 19.32, \delta_{\mathrm{C}} 13.25, \delta_{\mathrm{C}} 12.72\right.$, $\left.\delta_{\mathrm{C}} 12.43\right)$ along with nine methylenes, seven methines, and
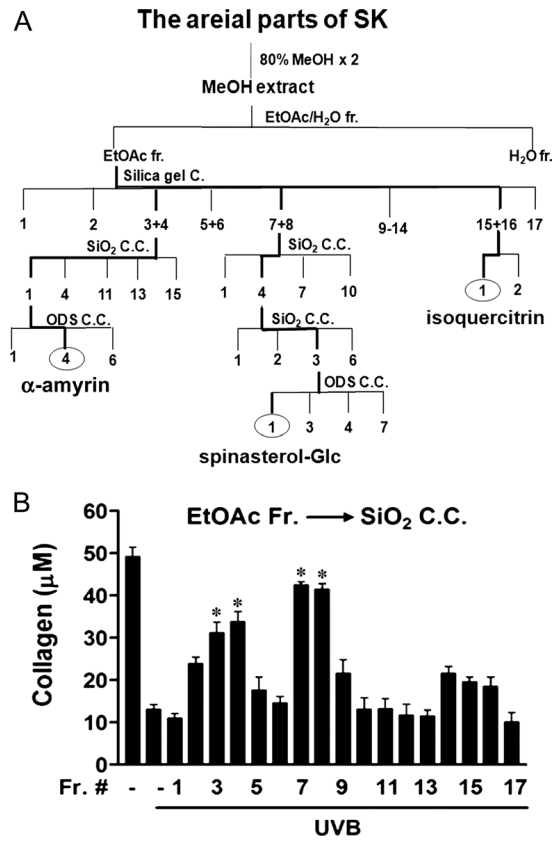

Fig. 1. Isolation Scheme of Active Compounds from the Leaves of Stewartia koreana and Activities of the Fractions of $\mathrm{SiO}_{2}$ Column Chromatography of EtOAc Extract for Collagen Production

(A) Isolation scheme of spinasterol-Glc by repeated $\mathrm{SiO}_{2}$ and ODS column chromatography of EtOAc extract. Triterpenoid and isoquercitrin were also isolated from different fractions of the first $\mathrm{SiO}_{2}$ chromatography. (B) Fibroblasts cells were pretreated with $10 \mu \mathrm{g} / \mathrm{ml}$ of each fraction for $24 \mathrm{~h}$ and exposed to UVB $\left(20 \mathrm{~mJ} / \mathrm{cm}^{2}\right)$. UVtreated cells were then cultured in the serum free medium for $24 \mathrm{~h}$. Total collagen levels were measured in the culture media of UVB-treated cells by SirCol assay. Data shown are the mean values \pm S.D. $(n=3) . * p<0.05$ versus UV-irradiation alone.

two quaternaries carbons, which are identical to those of spinasterol. ${ }^{24)}$ Consequently, the compound was identified as 3-O- $\beta$-D-glucopyranosylspinasterol (Fig. 2A). Other compounds, $\alpha$-amyrin and isoquercitrin were also isolated from fraction SKE3 and 4 and fraction SKE14 and 16 respectively and the structures were determined by similar experimental procedures, which are shown in Fig. 2A. It has been previously reported that triterpenoid has a variety of biological activities including inhibitory activity of MMP-1 expression in UV-irradiated cells. ${ }^{25)}$ Spinasterol-Glc promoted collagen production in UVB-irradiated NHDF up to the level of non-treated cells, which is comparable to retinol, well-known UV-protective agent, while $\alpha$-amyrin and isoquercitrin showed moderate or very weak activities, compared to spinasterol-Glc for promoting collagen production in UVB-treated NHDF, respectively (data not shown).

Inhibitory Effect of 3-O- $\boldsymbol{\beta}$-D-Glucopyranosylspinasterol (Spinasterol-Glc) on UVB-Induced Collagen Reduction First, we examined the effect of the most active compound spinasterol-Glc, among isolated compounds on cell viability of NHDF cells. As shown Fig. 2B, spinasterol-Glc does not inhibit cell viability up to $20 \mu \mathrm{M}$ concentration. Next, we analyzed collagen levels in the supernatant of control (no UVBirradiation) and UVB-treated NHDF. Fibroblast cells were treated with spinasterol-Glc at varying concentrations up to $10 \mu \mathrm{M}$ for $24 \mathrm{~h}$, exposed to UVB for $15 \mathrm{~s}\left(20 \mathrm{~mJ} / \mathrm{cm}^{2}\right)$ and incubated for $24 \mathrm{~h}$. Our results showed that spinasterol-Glc stimulated production of collagen in UVB-irradiated fibroblast cells in a concentration-dependent manner. However, collagen levels were not increased significantly by treatment 
A

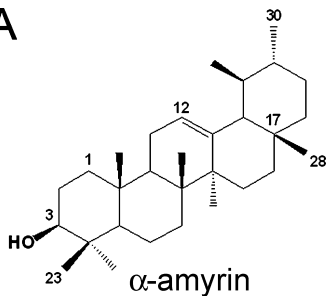<smiles>O=c1c(O)c(-c2ccc(O)c(O)c2)oc2cc(O)cc(O)c12</smiles>

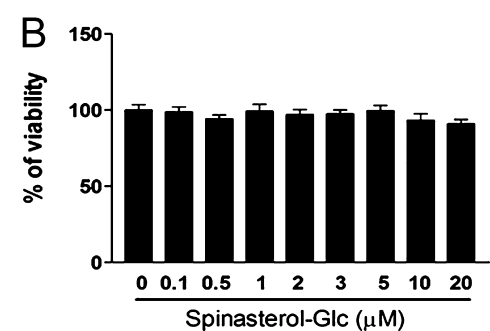

Fig. 2. Chemical Structures of Isolated Compounds and the Effects of Spinasterol-Glc on Cell Viability

(A) Chemical structures of $\alpha$-amyrin, spinasterol-Glc and isoqurcitrin from Stewarita koreana. (B) Fibroblast cells were grown in the culture medium in the presence of various concentrations of spinasterol-Glc for $48 \mathrm{~h}$. Cell viability was measured by MTT assays. All data are given as means \pm S.D. of at least three independent experiments with triplicate samples.

with spinasterol-Glc in non-irradiated fibroblast cells as shown in Fig. 3A. Upon treatment of UVB-irradiated fibroblast cells with spinasterol-Glc, the collagen levels were restored to $91 \%$ of the UVB-untreated control level at $10 \mu \mathrm{M}$ $(p<0.01)$ and to $61 \%$ at $1.25 \mu \mathrm{M}$ of spinasterol-Glc $(p<$ 0.05 ). Our results demonstrate that collagen levels in UVBirradiated fibroblast cells treated with spinasterol-Glc increased approximately three times more than those in vehicle-treated control cells, suggesting that spinasterol-Glc may stimulate expression of procollagen and/or inhibit MMP gene expression in UVB-irradiated fibroblast cells.

Effect of 3- $\boldsymbol{O}$ - $\boldsymbol{\beta}$-D-Glucopyranosylspinasterol (Spinasterol-Glc) on Procollagen Expression In order to test the effects of spinasterol-Glc on the synthesis of procollagen I, we investigated the mRNA and protein levels of procollagen in control human fibroblasts cells (no UVB irradiation) and in UVB-irradiated cells in the presence or absence of various concentrations of spinasterol-Glc. Reverse transcription (RT)PCR analysis showed that treatment of cells with spinasterolGlc resulted in stimulation of procollagen expression in UVB-stimulated fibroblast cells in a concentration-dependent manner. The protein levels of the procollagen were similarly increased in UVB-irradiated human fibroblast cells treated with spinasterol-Glc in concentration-dependent manner. However, spinasterol-Glc appears not to stimulate mRNA and protein expression levels of procollagen in control fibroblast cells significantly (Figs. 3B, C).

Effects of 3-O- $\beta$-D-Glucopyranosylspinasterol (Spinasterol-GIc) on Matrix Metalloprotease-1 (MMP-1) It has
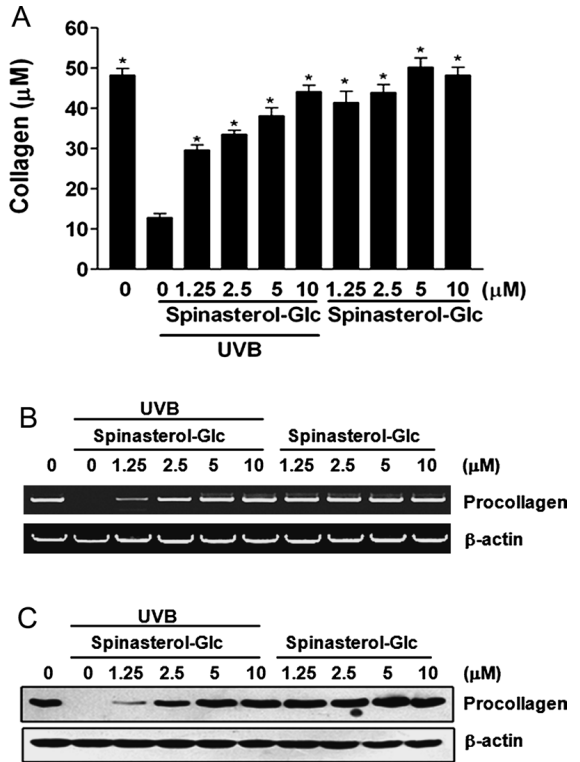

Fig. 3. Effect of 3-O- $\beta$-D-Glucopyranosylspinasterol on Collagen Production and Procollagen Expression in UVB-Irradiated Fibroblast Cells

Fibroblasts cells were pretreated with various concentrations of spinasterol-Glc for $24 \mathrm{~h}$ and exposed to UVB $\left(20 \mathrm{~mJ} / \mathrm{cm}^{2}\right)$. Control cells (no UVB irradiation) or UVB-irradiated fibroblast cells were then cultured in the serum free medium for $24 \mathrm{~h}$. (A) Total collagen levels were measured in the culture media of control cells or UVB-treated cells by SirCol assay. Data shown are mean values \pm S.D. $(n=3) . * p<0.05$ versus UVirradiation alone. (B) Levels of procollagen mRNA were determined by RT-PCR analysis. $\beta$-Actin mRNA was used as an internal control. (C) Levels of procollagen proteins were measured by western blot analysis using a monoclonal antibody against human procollagen. The blot underwent rehybridization with antibody against $\beta$-actin to verify equal loading of proteins in each lane.

been recently reported that a number of compounds isolated from natural plants may prevent or mitigate the UV-induced skin aging process through inhibition of MMP-1 expression. Thus, we investigated whether the increased level of collagen in spinasterol-Glc-treated cells was partly due to inhibition of MMP-1 expression by spinasterol-Glc. MMP-1 mRNAs levels were determined in human fibroblasts cells treated with UVB, in the presence of various concentrations of spinasterol-Glc. RT-PCR analysis showed that treatment of cells with spinasterol-Glc resulted in inhibition of the elevated MMP-1 gene expression in UVB-stimulated fibroblast cells in a concentration-dependent manner, without affecting the mRNA levels of $\beta$-actin (Fig. 4A). The protein levels of MMP-1 were analyzed by western blot analysis, showing that the protein levels of MMP-1 were significantly decreased in human fibroblast cells treated with spinasterol-Glc compared to that of non-treated cells (Fig. 4B). The reduced protein levels of MMP-1 correlated well with the levels of MMP-1 mRNA expression.

\section{DISCUSSION}

Collagens are major structural components of the extracellular matrix of dermal connective tissue, and its reduction has been suggested to be a major cause of skin wrinkling during photoaging. In this study, we isolated and identified spinasterol-Glc as an active compound that can protect human dermal fibroblast cells from collagen reduction resulting from UV irradiation. We demonstrate that the compound promoted collagen production via stimulation of procollagen production, as well as via inhibition of MMP-1 expression in 
A

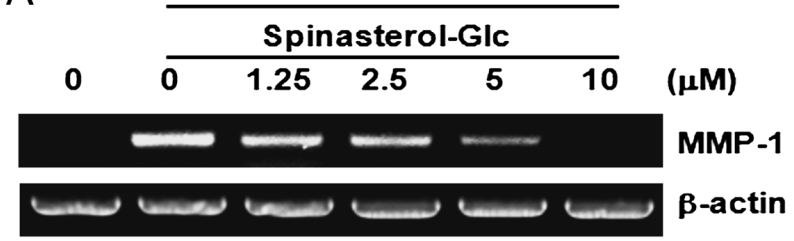

B

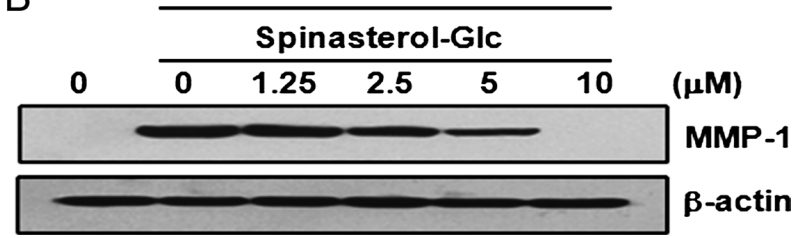

Fig. 4. Effect of 3-O- $\beta$-D-Glucopyranosylspinasterol on Matrix Metalloproteinase-1 (MMP-1) Gene Expression

Fibroblasts cells were pretreated with various concentrations of spinasterol-Glc for $24 \mathrm{~h}$ and exposed to UVB $\left(20 \mathrm{~mJ} / \mathrm{cm}^{2}\right)$. UV-treated cells were then cultured in the serum-free medium for $24 \mathrm{~h}$. (A) Levels of MMP-1 mRNA were determined by RTPCR analysis. $\beta$-Actin mRNA was used as an internal control. (B) Levels of MMP-1 protein were measured by western blot analysis using a monoclonal antibody against human MMP-1. The blot underwent rehybridization with antibody against $\beta$-actin to verify equal loading of proteins in each lane.

UV-irradiated human dermal fibroblast cells. These findings suggest that spinasterol-Glc is a potential agent for skin protection from UV irradiation and from photoaging of skin.

Spinasterol has been isolated from a number of plants and shown to exert various biological activities, including antitumor and antiulcerogenic acitivity. ${ }^{26-28)}$ A glycosidic spinasterol, 3-O- $\beta$-D-glucopyranosyl-spinasterol is known to be found mainly in fungi, but very rarely in plants. ${ }^{24)}$ Biological activities of spinasterol-Glc are largely unknown. We previously reported that methanol extract of Stewartia koreana stimulates neovasculization in vivo and also observed that it promotes wound healing on the skin of mice. ${ }^{20)}$ In this study, we isolated a number of compounds, including $\alpha$-amyrin, isoquercitrin, and spinasterol-Glc, from active fractions of SKE and demonstrated that among the isolated compounds, spinasterol-Glc exhibited the strongest stimulatory effect on production of collagen in UVB-irradiated fibroblast cells.

Type I procollagen is composed of two polypeptide chains, pro $\alpha 1$ (I) and pro $\alpha 2$ (I), at the ratio of two to one, respectively. There are various biological factors that can either induce or inhibit collagen biosynthesis at various levels of gene expression. It has been shown that tumor growth factor$\beta$ (TGF- $\beta$ ) is the major regulator of type 1 procollagen production. ${ }^{29,30)}$ UV irradiation inhibits TGF- $\beta$ signaling pathways that lead to a reduction of type 1 procollagen. It has been reported that many plant extracts stimulate collagen production and inhibit matrix metalloproteinases during photoaging. ${ }^{13,16)}$ Most plant-derived compounds promote collagen production in human skin fibroblasts via inhibition of MMP expression ${ }^{31)}$ but only a few plant-derived compounds, such as obovatol, have been reported to stimulate collagen synthesis. ${ }^{21)}$ Our results suggest that spinasterol-Glc may stimulate expression of pro $\alpha 1$ (I) and/or pro $\alpha 2$ (I) genes in fibroblast cells.

UV irradiation is reported to induce the synthesis of matrix metalloproteinases (MMPs). It was suggested that matrix degradation by UV-induced MMPs contributes sub- stantially to connective tissue damage during photoaging. ${ }^{5)}$ Among the MMPs, MMP-1 (fibroblast collagenase) is mainly responsible for collagen breakdown in skin. Thus, development of MMP-1 inhibitors is considered to be a promising strategy to increase synthesis of type I procollagen for photoaging and skin cancer therapies. It was reported that the activity of MMP-1 is regulated primarily at the level of transcription activity. We examined the production of MMPs involved in matrix degradation, and found that UVB-induced MMP-1 mRNA expression was significantly inhibited by spinasterol-Glc in a concentration-dependent manner. We also observed that UVB-induced MMP-1 protein expression was also inhibited by spinasterol-Glc treatment, compared to control cells. However, spinasterol-Glc did not affect the expression of the MMP-2 gene (data not shown). These results correlated well with a previous report that UV irradiation of cultured human skin fibroblasts induced upregulation of MMP-1, but had no effect on MMP-2. ${ }^{31)}$

In conclusion, the present study has shown that spinasterol-Glc isolated from Stewartia koreana promotes production of collagen in UV-irradiated fibroblast cells via stimulation of procollagen synthesis and via inhibition of MMP-1 expression. The underlying mechanisms by which spinasterol-Glc stimulates production of collagen and also inhibits MMP-1 expression in UV-irradiated fibroblast cells need to be elucidated. These findings suggest that spinasterol-Glc could be utilized as an effective agent in preventing the process of UVB-mediated cutaneous alterations and photoaging.

Acknowledgement This research was supported by a Grant from Kyung Hee University, Republic of Korea (KHU20100161).

\section{REFERENCES}

1) Rittié L., Fisher G. J., Ageing Res. Rev., 4, 705-720 (2002).

2) González S., Fernández-Lorente M., Gilaberte-Calzada Y., Clin. Dermatol., 26, 614-26. (2008).

3) Cao C., Wan Y., J. Cell Physiol., 220, 277-284 (2009).

4) Kavitha O., Thampan R. V., J. Cell Biochem., 104, 1150-1160 (2008).

5) Fisher G. J., Kang S., Varani J., Bata-Csorgo Z., Wan Y., Datta S., Voorhees J. J., Arch. Dermatol., 138, 1462-1470 (2002).

6) Cutroneo K. R., J. Cell Biochem., 90, 1-5 (2003).

7) Fisher G. J., Quan T., Purohit T., Shao Y., Cho M. K., He T., Varani J., Kang S., Voorhees J. J., Am. J. Pathol., 174, 101-114 (2009).

8) Choi C. P., Kim Y. I., Lee J. W., Lee M. H., Clin. Exp. Dermatol., 32, 180-185 (2007).

9) Buechner N., Schroeder P., Jakob S., Kunze K., Maresch T., Calles C., Krutmann J., Haendeler J., Exp. Gerontol., 43, 633-637 (2008).

10) Dong K. K., Damaghi N., Picart S. D., Markova N. G., Obayashi K., Okano Y., Masaki H., Grether-Beck S., Krutmann J., Smiles K. A., Yarosh D. B., Exp. Dermatol., 17, $1037-1044$ (2008).

11) Leu S. J., Lin Y. P., Lin R. D., Wen C. L., Cheng K. T., Hsu F. L., Lee M. H., Biol. Pharm. Bull., 29, 740-745 (2006).

12) Tanaka K., Hasegawa J., Asamitsu K., Okamoto T., Eur. J. Pharmacol., 565, 212-219 (2007).

13) Fujii T., Wakaizumi M., Ikami T., Saito M., J. Ethnopharmacol., 119, 53-57 (2008).

14) Philips N., Conte J., Chen Y. J., Natrajan P., Taw M., Keller T., Givant J., Tuason M., Dulaj L., Leonardi D., Gonzalez S., Arch. Dermatol. Res., 301, 487-495 (2009).

15) Park H. M., Moon E., Kim A. J., Kim M. H., Lee S., Lee J. B., Park Y. K., Jung H. S., Kim Y. B., Kim S. Y., Int. J. Dermatol., 49, 276-282 (2010).

16) Moon H. J., Lee S. R., Shim S. N., Jeong S. H., Stonik V. A., Rasska- 
zov V. A., Zvyagintseva T., Lee Y. H., Biol. Pharm. Bull., 31, 284 289 (2008).

17) Tanaka K., Hasegawa J., Asamitsu K., Okamoto T., J. Pharmacol. Exp. Ther., 315, 624-630. (2005).

18) Kim Y. G., Sumiyoshi M., Sakanaka M., Kimura Y., Eur. J. Pharmacol., 602, 148-156. (2009).

19) Lee T. B., "Coloured Flora of Korea," 1st ed., Vol. I, HyangMoon-Sa, Seoul, 2003, p. 741 .

20) Lee T. H., Lee G. W., Kim C. W., Bang M. H., Baek N. I., Kim S. H., Chung D. K., Kim J,. Phytother. Res., 24, 20-25 (2010).

21) Choi M. S., Yoo M. S., Son D. J., Jung H. Y., Lee S. H., Jung J. K., Lee B. C., Yun Y. P., Pyo H. B., Hong J. T., J. Dermatol. Sci., 46, 127-137 (2007).

22) Huber L. C., Distler J. H., Moritz F., Hemmatazad H., Hauser T., Michel B. A., Gay R. E., Matucci-Cerinic M., Gay S., Distler O., Jüngel A., Arthritis Rheum., 8, 2755-2764 (2007).

23) Lee T. H., Kwak H. B., Kim H. H., Lee Z. H., Chung D. K., Baek N. I., Kim J., Mol. Cells, 23, 398-404 (2007).
24) Zhang L. J., Yang X. D., Xu L. Z., Zou Z. M., Yang S. L., J. Asian Nat. Prod. Res., 7, 649-653 (2005).

25) Moon H. I., Kim M. R., Woo E. R., Chung J. H., Biol. Pharm. Bull., 28, 2003-2006 (2005).

26) Ravikumar Y. S., Mahadevan K. M., Manjunatha H., Satyanarayana N. D., Phytomedicine, 17, 513-518 (2010).

27) Klein L. C. Jr., Gandolfi R. B., Santin J. R., Lemos M., Cechinel Filho V., de Andrade S. F., Naunyn Schmiedebergs Arch. Pharmacol., 381, $121-126$ (2010).

28) Jeon G. C., Park M. S., Yoon D. Y., Shin C. H., Sin H. S., Um S. J., Exp. Mol. Med., 37, 111-120. (2005).

29) Chen S. J., Yuan W., Mori Y., Levenson A., Trojanowska M., Varga J., J. Invest. Dermatol., 112, 49-57 (1999).

30) Ghosh A. K., Mori Y., Dowling E., Varga J., Biochem. Biophys. Res. Commun., 354, 420-426 (2007).

31) Moon H. I., Kwak J. H., Zee O. P., Chung J. H., Biol. Pharm. Bull., 28, $2173-2175$ (2005). 